\title{
Alligatorweed Stem Borer (suggested common name) Arcola malloi Pastrana (Insecta: Lepidoptera: Pyralidae: Phycitinae) ${ }^{1}$
}

\author{
Bonnie C. Wells and Carey Minteer ${ }^{2}$
}

\section{Introduction}

The alligatorweed stem borer, Arcola malloi, is a snout moth introduced to the southeastern United States in 1971 from South America as a biological control agent to suppress the growth of the water-impeding Amaranth weed species, Alternanthera philoxeroides, commonly known as alligatorweed. The alligatorweed stem borer presently occurs in Florida and other southeastern US states where it was introduced. The phytophagous larvae synergistically suppress alligatorweed, along with the alligatorweed flea beetle, Agasicles hygrophila (Coleoptera: Chrysomelidae).

The alligatorweed stem borer is related to several important pest moth species, including pests of crops, pests of stored products, and pests of turfgrass and beehives-for example, the lesser cornstalk borer, flour moths, sod webworms, and wax moths. It is also a relative to the important biological control agent of invasive Opuntia, the cactus moth.

\section{Synonymy}

Arcola malloi (Pastrana 1961)

Vogtia malloi (Pastrana 1961)

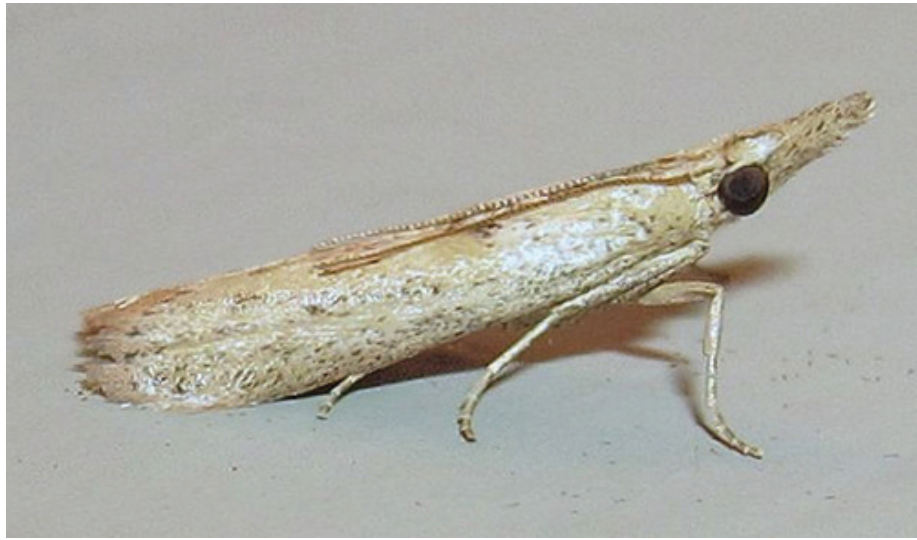

Figure 1. The alligatorweed stem-borer moth, Arcola malloi Pastrana. Credits: Peter Homan, University of Florida

\section{Distribution}

The alligatorweed stem borer is native to South America from Argentina to Guyana (Coombs 2004) but occurs in the southeastern United States, Australia, and New Zealand where it was introduced as a biological control agent. The moth was first released in the United States in May of 1971 in Florida, Georgia, North Carolina, and South Carolina. It was released in Alabama in 1972 (Coulson 1977). It was released in Australia in 1997 and in New Zealand in 1984 (CABI 2020).

Macrorrhinia endonephele (Hampson)

1. This document is EENY-764, one of a series of the Entomology and Nematology Department, UF/IFAS Extension. Original publication date August 2020. Visit the EDIS website at https://edis.ifas.ufl.edu for the currently supported version of this publication. This document is also available on the Featured Creatures website at http://entomology.ifas.ufl.edu/creatures.

2. Bonnie C. Wells, Extension agent II, commercial horticulture, UF/IFAS Extension Brevard County; and Carey Minteer, assistant professor, UF/IFAS Indian River Research and Education Center; UF/IFAS Extension, Gainesville, FL 32611.

The Institute of Food and Agricultural Sciences (IFAS) is an Equal Opportunity Institution authorized to provide research, educational information and other services

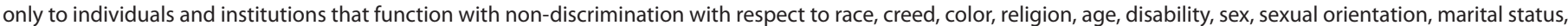

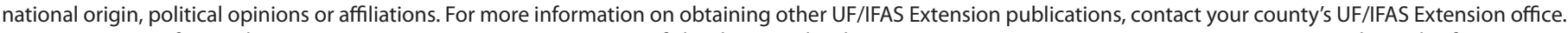
U.S. Department of Agriculture, UF/IFAS Extension Service, University of Florida, IFAS, Florida A \& M University Cooperative Extension Program, and Boards of County Commissioners Cooperating. Nick T. Place, dean for UF/IFAS Extension. 


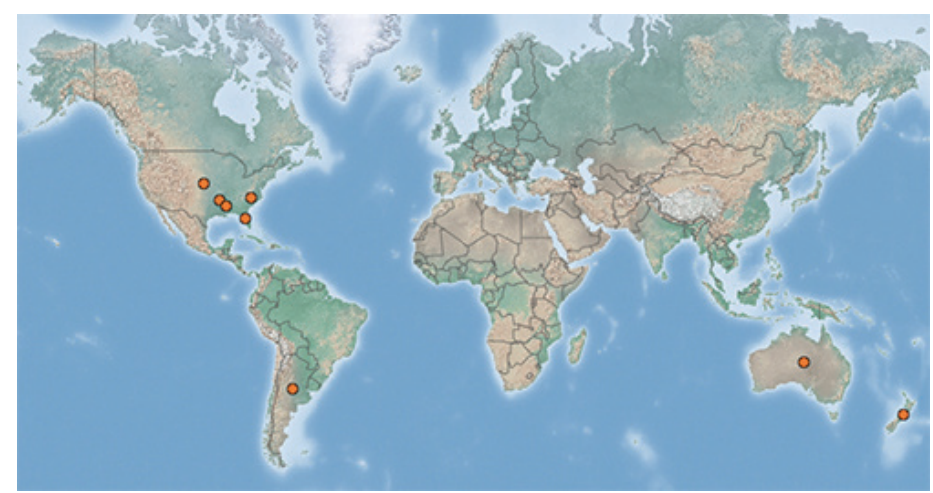

Figure 2. Distribution map of the alligatorweed stemborer, Arcola malloi Pastrana.

Credits: $\mathrm{CABI}$

\section{Description}

\section{Egg}

Adult female moths deposit oval eggs singly on the undersides of apical leaves, near the leaf margin, in the midvein or in the leaf axil. Egg size is around $0.7 \mathrm{~mm} \times 0.44$ $\mathrm{mm}$, and eggs first appear white then become yellow as the embryo develops (Center et al. 2002).

\section{Larva}

Larva are whitish and marked with wavy, tan, longitudinal stripes (Buckingham 2004). There are five instars (Maddox 1970).

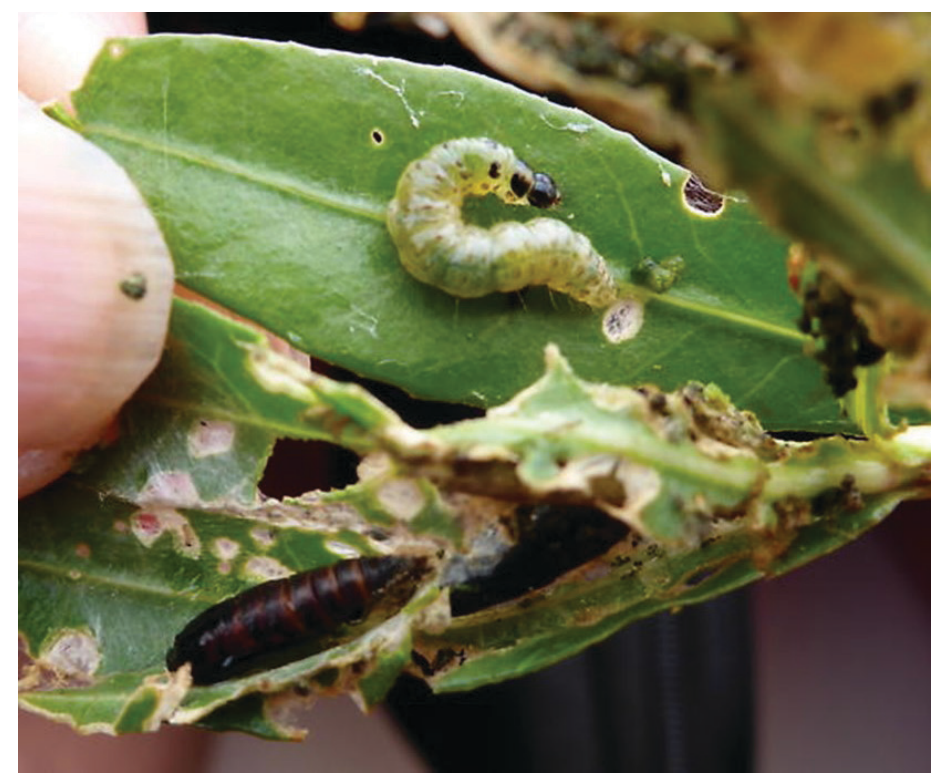

Figure 3. Larva and pupa of the alligatorweed stemborer, Arcola malloi Pastrana.

Credits: Marylyn Feaver, University of Florida

\section{Pupa}

Pupa are amber colored and darken as they develop inside silken cocoons (Buckingham 2004).

\section{Adult}

Arcola malloi adults are light-tan, inconspicuous moths with a wingspan of up to $20 \mathrm{~mm}$. Wings are dashed with brown scales on the edge and wing tip. The forewings have smooth scales with ten veins. When the moth is at rest, its wings are folded and curled partly around its body, with wing tips lying against the plant but with its head held up with the body at an angle with the plant (Buckingham 2002).

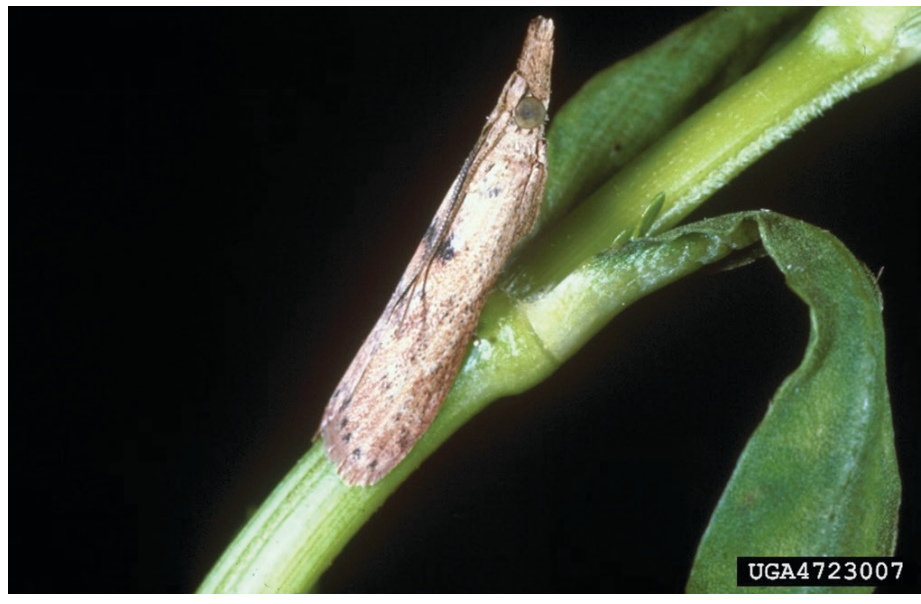

Figure 4. Arcola malloi Pastrana adults are small, tan moths that hold their wings close to the body when at rest.

Credits: Willey C. Durden, USDA ARS, bugwood.org

\section{Life Cycle}

The life cycle of the alligatorweed stem borer from egg to egg is approximately 39 days at $23^{\circ} \mathrm{C}$. Adult moths oviposit an average of 200 to 300 eggs on the underside of apical leaves of alligatorweed plants over a 6- to 8-day period. Eggs hatch in 3-4 days after oviposition. Newly hatched larvae immediately tunnel into stems through the first to fourth internodes of the apical stem portion and bore downwards. More developed larvae may enter stems at a lower level and burrow upwards, devouring plant tissues (Center et al. 2002). As the larvae develop, they can drop down on silken threads to bore into other stems (Buckingham 2002). Five instars of larvae develop within 24 days (Maddox 1970). Larval feeding occurs throughout the stem. The larvae chew circular holes approximately $2 \mathrm{~mm}$ in diameter through the stem wall (Center et al. 2002). The larvae seal holes with masticated tissues at the nodes along the stem to prevent water intrusion.

Pupation occurs in the stem in silken cocoons. Adult moths emerge by rupturing the thin epidermis covering the hole previously created by the mature larvae. Adults are nocturnal, remaining quiescent during the day. Females can live approximately 6 to 10 days and males approximately 5 to 9 days. The insect develops most rapidly during hot, dry 
periods (Kay 1989). Only the larvae stage of Arcola malloi feed on alligatorweed (Center et al. 2002).

Three to four generations per year were reported in Argentina (Maddox 1970). It was reported having more than two generations annually in the lower Mississippi River Valley (Vogt et al. 1992). It was also documented by Vogt et al. (1992) that Arcola malloi migrated to more northern regions (Arkansas and north Mississippi) from winter refuges in Louisiana at a distance up to $1000 \mathrm{~km}$.

\section{Hosts}

Alligatorweed (Alternanthera philoxeroides [Mart.] Griseb.) is the main host of the alligatorweed stem borer, but occasionally the borer will feed on Silverhead, Blutaparon vermiculare, and yellow joyweed, Alternanthera flavescens. However, development of younger larvae (first to third instars) is restricted to alligatorweed (Maddox and Hennessey 1970).

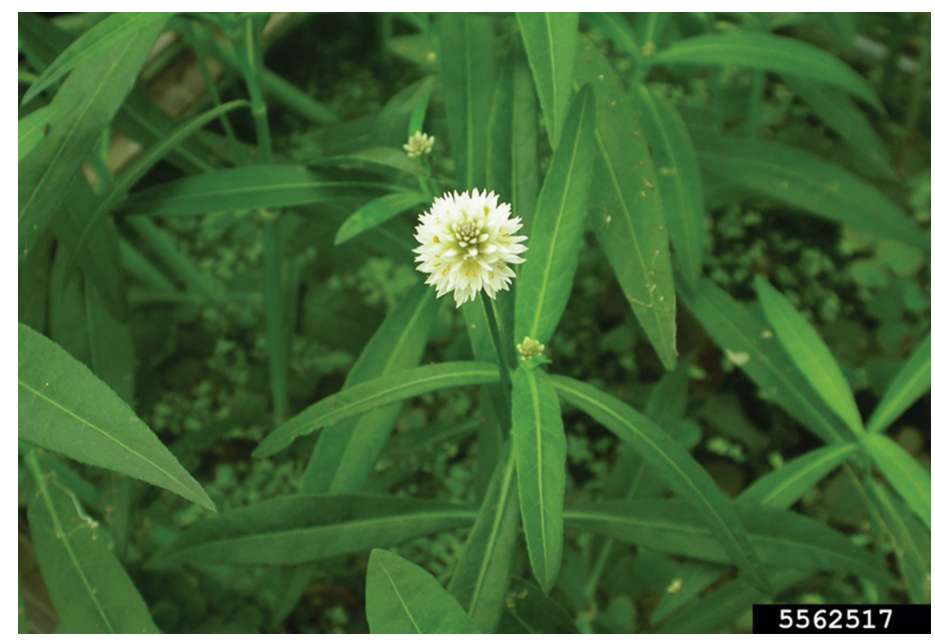

Figure 5. Alligatorweed, Alternathera philoxeroides [Mart.] Griseb., is the main host plant of Arcola malloi Pastrana.

Credits: Shaun Winterton, Aquarium and Pond Plants of the World, Edition 3, USDA APHIS PPQ, Bugwood.org

\section{Importance}

The alligatorweed stem borer, Arcola malloi, is an important natural enemy of one of the world's worst aquatic weeds, Alternanthera philoxeroides or alligatorweed. It was released in the United States in 1971, and since has become one of the greatest success stories in the history of biological weed control due to its ability to suppress the growth of alligatorweed along with the alligatorweed flea beetle, Agasicles hygrophila (Kay 1989).

Alligatorweed is an anchored, floating plant whose roots spread rapidly along waterways forming thick mats above and below the water surfaces, disrupting many economic uses. Drainage canals, ditches, streams, and other water bodies can become clogged with thick mats of the weed preventing emptying during heavy rains which leads to flooding, as well as causing obstructions in navigation near bridges, dams, and narrow paths in waterways (Buckingham 2002). In addition, thick mats of alligatorweed increase mosquito populations, reduce water oxygen levels and sedimentation, and displace native plants and animals in ditches, along banks, and in shallow water (Holm et al. 1997). Alligatorweed can also infest terrestrial habitats during dry periods (Driesche et al. 2002). Alligatorweed is a noxious weed, federally prohibited in Florida, South Carolina, Arizona, and California (USDA, NRCS 1999).

\section{Damage}

The alligatorweed stem borer attacks both aquatic and terrestrial alligatorweed, but it prefers aquatic plants. It feeds within the stems of the weed causing reduced nutrient flow through, thereby causing stems to collapse, turn yellow, and die (Brown and Spencer 1973).

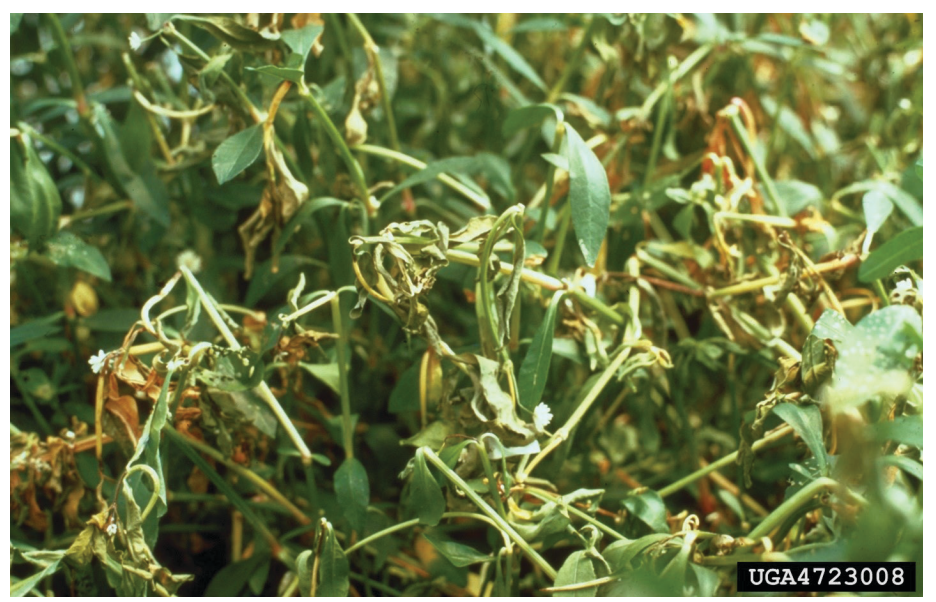

Figure 6. Alligatorweed stems damaged internally by the larvae of Arcola malloi Pastrana wilt, turn yellow, and die.

Credits: USDA ARS, bugwood.org

The larva is the only feeding stage of Arcola malloi. A single, developing larva can destroy up to nine stems prior to pupation (Kay 1989). The feeding damage of the alligatorweed stem borer is synergistic with the alligatorweed flea beetle in suppressing alligatorweed when environment is optimum (Kay 1989). The flea beetle adults feed on alligatorweed leaves, stripping them from the stems, while the alligatorweed stem borer enters stems and feeds on the vascular tissues from the inside out, limiting the growth of the dense, mat-forming alligatorweed (Coombs 2004). 


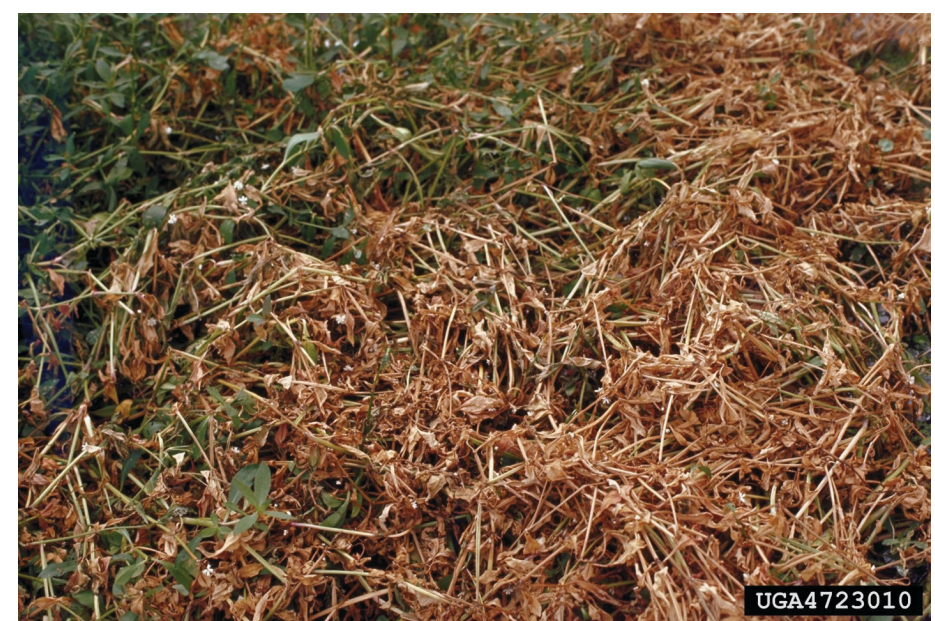

Figure 7. Alligatorweed mats turn yellow but still retain leaves in contrast to the yellow stems defoliated by the alligatorweed flea beetle, Agasicles hygrophila Selman and Vogt.

Credits: USDA ARS, bugwood.org

\section{Selected References}

Brown JL, Spencer NR. 1973. "Vogtia malloi, a newly introduced phycitine moth (Lepidoptera: Pyralidae) to control alligatorweed." Environmental Entomology 2:519-523.

Buckingham GR. 2002. Alligatorweed. In: van Driesche R, Blossey B, Hoddle M, Lyon S and Reardon R (editors) Biological Control of Invasive Plants in the Eastern United States, pp. 5-15. USDA Forest Service Publication FHTET-2002-04 (30 April 2020)

Buckingham GR. 1996. "Biological control of alligatorweed, Alternanthera philoxeroides, the world's first aquatic weed success story." Castanea 61:232-243.

CABI. 2020. Alternanthera philoxeroides (alligatorweed) In: Invasive Species Compendium. Wallingford, UK: CAB International. (5 January 2020)

Center TD, Dray AF, Vandiver V. 2002. Biological Control with Insects: The Alligatorweed Stem-borer. Department of Agronomy, Florida Cooperative Extension Service, Institute of Food and Agricultural Sciences, University of Florida. SS-AGR-134. (21 April 2020)

Coombs EM, Clark JK, Piper GL, Cofrancesco AF. (editors). 2004. Biological Control of Invasive Plants in the United States. Corvallis. Oregon State University Press. pp. 146-149.

Coulson JR. 1977. Biological control of alligatorweed, 1959-1972. A review and evaluation. Technical Bulletin No. 1547, USDA-ARS, Washington, D.C., 98 pp.
Hayden, JE, Landry, JF. 2020. “Arcola malloi (Pastrana), the alligatorweed stem borer, a new synonym of Macrorrhinia endonephele (Hampson) (Lepidoptera: Pyralidae: Phycitinae)." Insect Mundi 0768:1-25.

Holm L, Doll JE, Holm J, Pancho J, Herberger J. 1997. World Weeds: Natural Histories and Distribution. John Wiley and Sons, New York. pp. 37-44.

Kay SH. 1989. Biological control of aquatic weeds with insects. Proceedings of Workshop on Management of Aquatic Weeds and Mosquitoes in Impoundments. University of North Carolina. pp. 73-82. (30 April 2020)

Maddox DM. 1970. “The Bionomics of a Stem Borer, Vogtia malloi (Lepidoptera: Phycitidae) on Alligatorweed in Argentina." Annals of the Entomological Society of America 63:1267-1273. https://doi.org/10.1093/aesa/63.5.1267

Maddox DM, Hennessey RD. 1970. The biology and host range of Vogtia malloi Pastrana, unpublished report. U.S. Department of Agriculture, Agricultural Research Service, Entomological Research, Entomological Research Division, Albany, California, USA.

Pastrana JA. 1961. "Una nueva Phycitidae (Lep.) parasito de la 'lagunilla"' Revista de Investigaciones Agricolas 15:265-272.

Pemberton RW. 2000. "Predictable risk to native plants in weed biological control.” Oecologia 125:489-494.

Peterson A. 1963. "Egg types among moths of the Pyralidae and Phycitidae-Lepidoptera." The Florida Entomologist 46: 1-14. http://www.jstor.org/stable/3493354 (28 April 2020)

Solis MA. 2007. "Phylogenetic studies and modern classification of the Pyraloidea (Lepidoptera)." Revista Colombiana de Entomología 33:1-9. (26 April 2020)

USDA NRCS. 1999. United States Department of Agriculture, Natural Resources Conservation Service. Plants Database. http://plants.usda.gov (27 April 2020)

Vogt GB, Quimby JR PC, Kay SH. 1992. Effects of weather on the biological control of alligatorweed in the lower Mississippi Valley region, 1973-83. Technical Bulletin 1766. U.S. Department of Agriculture, Agricultural Research Service, Washington, D.C. 